\title{
Elaphidiini (Coleoptera, Cerambycidae) from the Caribbean region of Colombia: New species, taxonomic notes and new geographical records
}

\author{
Kimberly García' \& Francisco Eriberto de Lima Nascimento² \\ 1 Universidad del Atlántico (UA), Facultad de Ciencias Básicas, Programa de Biología, Semillero de investigación Artrópodos NEOPTERA del \\ Caribe Colombiano. Puerto Colombia, Atlántico, Colombia. ORCID: http://orcid.org/0000-0002-3631-180X. E-mail: kimberly.pg@gmail.com \\ 2 Universidade de São Paulo (USP), Museu de Zoologia (MZUSP). São Paulo, SP, Brasil. ORCID: http://orcid.org/0000-0002-5047-8921. \\ E-mail: eribnascimentofl@gmail.com
}

\begin{abstract}
Two new species of Elaphidiini from Colombia are described: Sphaerion costae sp. nov., and Mephritus costae sp. nov. The keys to species of Sphaerion Audinet-Serville, 1834 and Mephritus Pascoe, 1866 are translated and modified to include the new species. Chromatic variations of Mephritus apicatus (Linsley, 1935) are reported. Moreover, the geographical distribution is expanded for 12 species of Elaphidiini.
\end{abstract}

Key-Words. Sphaerion; Mephritus; Tropical dry forest; Longhorned beetles; Taxonomy.

\section{INTRODUCTION}

Elaphidiini Thomson, 1864 (Cerambycidae, (erambycinae) is a very diverse tribe, currently composed of 93 genera and 633 species (Tavakilian \& Chevillotte, 2019), with geographical distribution in the Americas (Martins, 2005). Elaphidiini is characterized by the presence of antennal and tibial carinae, and an abruptly rounded anterior margin of the mesonotum (Lingafelter, 1998). In Colombia, Elaphidiini is the second most diverse tribe, with 18 genera and 37 species (Botero, 2018).

Sphaerion Audinet-Serville, 1834 was created as a subdivision for Elaphidion AudinetServille, 1834 (Martins, 2005). The genus has had a complex taxonomic history, being synonymized many times with Nephalius Blanchard, 1843 and Mephritus Pascoe, 1866 (Martins, 2005). However, according to Lingafelter (1998) and Martins (2005), it differs from those genera in having a small projection at the posterior margin of the metepisternum, near posterior notch; prothorax rounded at lateral margins, without tubercles in males; very distinct sexual punctures on the lateral margins of the male's prothorax; antennomere I without or with very small spines in males. This genus currently contains eight species, occurring in North, Central and South America (Bezark, 2019). The new species described herein is the first known from Colombia. Additionally, Galileo et al. (2015) described Sphaerion iuasanga and mentioned that it can be included in the alternative of couplet
3, with S. sladeni and S. rusticum Burmesiter, 1865 in Martins (2005) key, but did not add the modified key in the text. Later, S. lingafelteri Galileo \& Santos-Silva, 2016 was described and added in the alternative of couplet 5 from Martins (2005) by Galileo \& Santos-Silva (2016). Herein, S. iuasanga and $S$. lingafelteri are added along with the new species in Martins (2005) modified key.

The genus Mephritus contains 22 species with geographical distribution restricted to Central and South America, none of which are reported from Colombia (Bezark, 2019). Mephritus is similar to Nephalius; the latter was synonymized by Gounelle (1907), but Napp \& Martins (1982) revalidated the genus, and mentioned its similarity with Mephritus. Later, Martins (2005), established the differences between Sphaerion and Mephritus (mentioned above), and created a key to the South American species of Mephritus. Galileo \& Martins (2011) described three new species from Brazil, and Galileo et al. (2014) described four new species and modified the key to include the 22 species currently known.

Herein, Sphaerion costae sp. nov., and Mephritus costae sp. nov., are described and illustrated. The keys proposed by Martins (2005), Galileo et al. (2014) and Galileo \& Santos-Silva (2016) are modified to include these new species. Additionally, we comment on and illustrate chromatic variation in Mephritus apicatus (Linsley, 1935), and the geographical distribution for 12 species of Elaphidiini is expanded. 


\section{MATERIAL AND METHODS}

The material examined was collected in two fragments of tropical dry forest in the Caribbean region of Colombia (Reserva Campesina la Montaña (RCM), Atlántico and Reserva La Flecha (RLF), Bolívar). The specimens were collected with the following techniques: white light trap, UV light trap, manual capture and fruit baited traps. The sampling was supplemented by visits to entomological collections.

The material in this study is deposited in the following institutions, which are subsequently referred to by their acronyms: CEUA: Colección Entomológica Universidad de Antioquia, Medellín, Colombia (Martha Wolff); IAVH: Instituto de Investigaciones de Recursos Biológicos "Alexander von Humboldt", Villa de Leyva, Colombia (Jhon Cesar Neita); ICN: Universidad Nacional de Colombia, Instituto de Ciencias Naturales, Bogotá, Colombia (Germán Amat); MEFLG: Museo entomológico "Francisco Luis Gallego", Universidad Nacional de Colombia. Medellín, Colombia (Sandra Uribe, John Alveiro Quiroz Gamboa); MNRJ: Universidade do Rio Janeiro, Museu Nacional, São Cristovão, Rio de Janeiro, Brazil (Marcela Monné); MPUJ: Pontificia Universidad Javeriana, Bogotá, Colombia (Igor Dimitri Forero, Giovanny Fagua); MZSP: Museu de Zoologia, Universidade de São Paulo, São Paulo, Brazil (Sônia Casari, Antonio Santos-Silva); UARC: Universidad del Atlántico, Puerto Colombia, Colombia (Neis José Martínez); UNAB: Universidad Nacional, Facultad de Agronomía, Bogotá, Colombia (Francisco Serna, Erika Valentina Vergara-Navarro).

Photographs were taken with a Canon EOS Rebel T3i DSLR camera, Canon MP-E 65 mm f/2.8 1-5× macro lens, controlled by Zerene Stacker focus stacking software. Measurements were taken in millimeters using Leica Application Suite (LAS 4.0) software and a Leica M125 stereomicroscope, also used in the study of specimens. The terminology used herein for morphological structures follows Lawrence et al. (2010).

\section{RESULTS}

\section{Mephritus costae sp. nov. (Figs. 1-4)}

Type material: Holotype ơ (MPUJ): Colombia, Bolívar: San Jacinto (Reserva La Flecha, 324 m, 09 $51^{\prime} 12.4^{\prime \prime} \mathrm{N}$, $75^{\circ} 10^{\prime} 41.4^{\prime \prime} \mathrm{W}$, tropical dry forest), 16.IV.2018, García, K. col., UV light trap, MPUJ_ENT 0069866.

Male: General Integument reddish-brown; elytra slightly light brown; mandibles and areas around its insertion, antennae, femoral apex and tibiae dark brown.

Head: Frons coarsely, densely punctate (Fig. 4), with short, whitish, decumbent setae evenly distributed, not obliterating integument. Vertex with same sculpturing as frons; area behind eyes with slightly coarser punctures. Postclypeus with sculpturing and pubescence as on frons (with long setae near margin). Labrum coarsely punctate; with long and short, yellowish setae. Gulamentum coarsely, densely punctate; with sparse whitish pubescence. Outer side of mandibles with yellowish short setae interspersed with a few, long setae, glabrous on anterior half. Distance between upper eye lobes about 2.5 times width of an upper eye lobe. Antennae reaching elytral apex by mid length of antennomere VIII. Scape gradually wider toward apex; with yellowish pubescence interspersed by suberect yellowish setae; remaining antennomeres with whitish pubescence interspersed by elongate suberect setae at inner side. Antennal formula (ratio) based on length of antennomere III: scape $=0.62$; pedicel $=0.18 ; \mathrm{IV}=0.80 ; \mathrm{V}=0.95 ; \mathrm{VI}=0.93 ; \mathrm{VII}=0.98$; $\mathrm{VIII}=0.75 ; \mathrm{IX}=0.72 ; \mathrm{X}=0.66 ; \mathrm{XI}=0.76$.

Thorax: Prothorax with moderately, yellowish pubescence, not obliterating integument. Pronotum with slightly elevated tubercles, two latero-anterior and two latero-posterior; with glabrous elongate median area; with coarse punctures near glabrous area. Lateral margins of prothorax with small obtuse tubercle at middle. Ventral thoracic surface with pubescence as on pronotum; with a dense punctation usually considered as sexually dimorphic in the species of this genus. Prosternal process about 0.3 times as wide as a procoxal cavity; mesoventral process 0.7 times as wide as mesocoxal cavity.

Elytra: Coarsely, abundantly punctate on basal half, gradually sparser toward apex; surface with sparse yellowish pubescence, not obliterating integument; with sparse, erect, elongate, brownish setae, especially on posterior third.

Legs: Femora slightly clavate; with sparse yellowish pubescence, not obliterating integument; with erect, elongate brownish setae dorsally. Tibiae coarsely granulate-punctate; with erect, elongate brownish setae.

Abdomen: Ventrites with yellowish, moderately abundant pubescence, not obscuring integument; ventrite I about 2 times the width of II (from abdominal process); III-IV subequal in width; ventrite $\mathrm{V}$ with yellow pubescence laterally, white centrally, both abundant but not obscuring integument; with a few long, erect, white setae laterally on ventrite I, yellowish-white on ventrites II-IV, and yellowish-white and yellowish-brown setae on ventrite $V$; ventrite $V$ about 0.6 times the width of IV, slightly notched at middle of apex.

Measurements (in $\mathbf{m m}$ ): Holotype, male, total length: 11.5, prothorax length: 2.1, largest prothoracic width: 2.6, elytral length: 8.0, humeral width: 3.0.

Etymology: The species epithet is in honor of Cleide Costa (MZSP) for her work and dedication to the knowledge of Coleoptera.

Remarks: Mephritus costae sp. nov., is included in the group of species without contrasting areas of color on 
elytra, which is composed by species with elytral coloration homogeneous, sometimes with apex or margin darkened (Galileo et al., 2014). The new species differs from M. guttatus Napp \& Martins, 1982, M. destitutus Napp \& Martins, 1982 and M. vescus Galileo \& Martins, 2011 especially by antennomere III longer and strong- ly, laterally compressed, and by the blackish tibiae. By the blackish tibiae, the new species is also similar to M. citreus Napp \& Martins, 1982, however, it differs by the well-marked pronotal tubercles and by the smaller elytral spines. It is important to mention that the new species is from a region geographically isolated from the four spe-
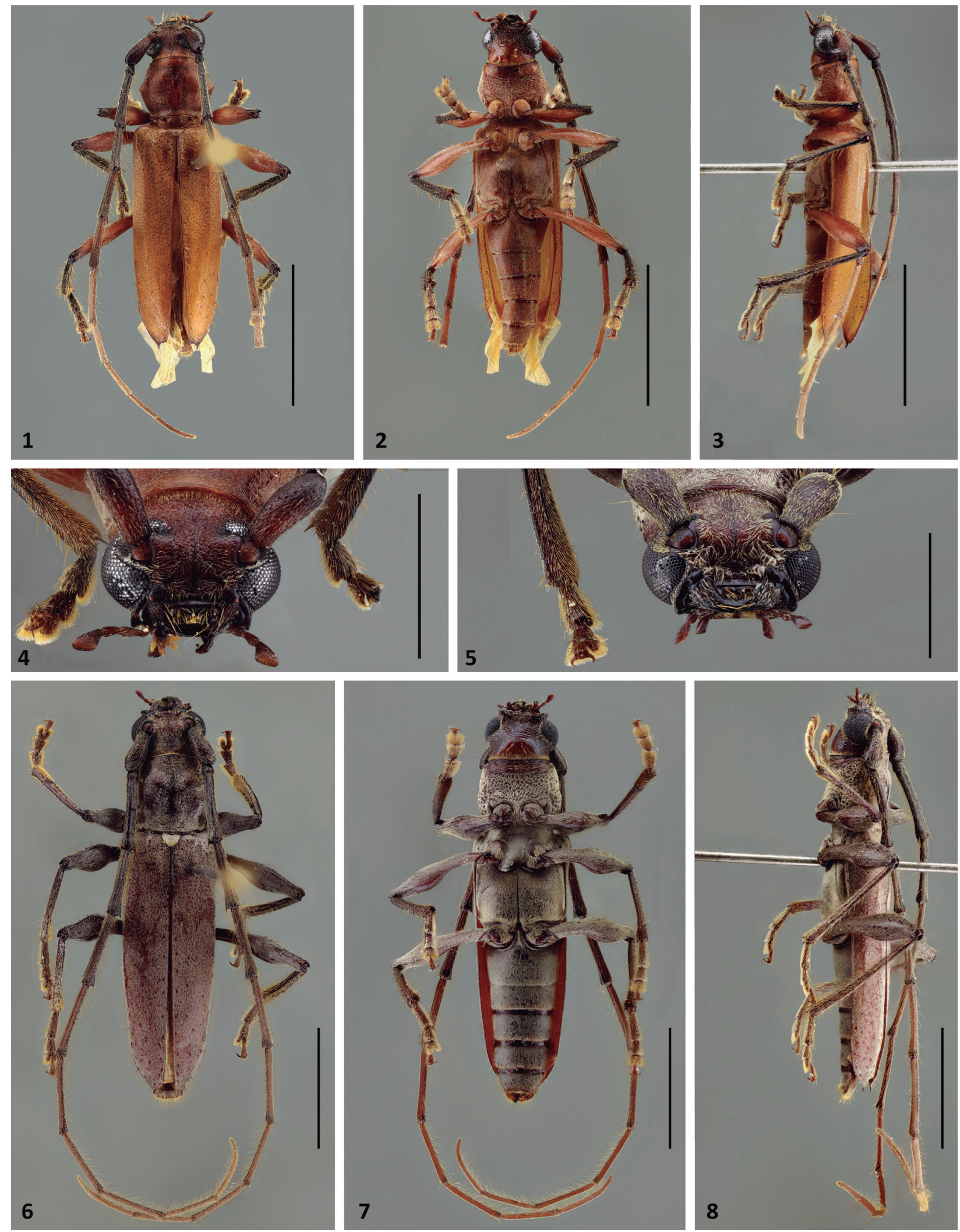

Figures 1-8. (1-4) Mephritus costae sp. nov. Holotype male: (1) Dorsal habitus; (2) Ventral habitus; (3) Lateral habitus; (4) Head, frontal. (5-8) Sphaerion costae sp. nov., holotype male: (5) Head, frontal; (6) Dorsal habitus; (7) Ventral habitus; (8) Lateral habitus. Scale bars: figs. 1-4=2 mm; figs. 5-8=5 mm. 
cies above. Mephritus costae sp. nov., is know from San Jacinto, a Caribbean region of Colombia, isolated by the Andes Mountain Range, while the other four species are known from the Atlantic forest or Amazonian region.

According to the key to species of Mephritus (Galileo et al., 2014), the new species can be inserted as follows (modified):

20(19). Antennae and legs reddish. Brazil (Goiás, Mato Grosso, Maranhão).. ..M. destitutus Napp \& Martins, 1982

- Basal flagellomeres and tibiae black, scape and femora reddish ..21'

$21^{\prime}(20)$. Pronotal tubercles well-marked; elytral spines small. Colombia (Bolívar). M. costae sp. nov.

- Pronotal tubercles poorly elevated; elytral spines long. Brazil (Bahia).. M. citreus Napp \& Martins, 1982

\section{Sphaerion costae sp. nov.}

(Figs. 5-8, 10-12)

Paratypes: COLOMBIA, Atlántico: Usiacurí (Reserva Campesina La Montaña, $260 \mathrm{~m}, 10^{\circ} 46.0^{\prime} 02.6^{\prime \prime} \mathrm{N}$, $75^{\circ} 00.2^{\prime} 34.0^{\prime \prime} \mathrm{W}$, tropical dry forest), 17-18.III.2018, García, K. col., white light trap (1 9 MNRJ), 12-14.V.2018, García, K. col., white light trap (3 o' MPUJ_ENT 0069868, MPUJ_ENT 0069869,MPUJ_ENT0069870,7\% MZSP,3 9 UARC,3 9 IAVH, $1 \sigma^{\prime}, 3$ \% CEUA, $1 \sigma^{\prime}, 3$ \% MEFLG, $1 \sigma^{\prime}, 2$ ᄋ ICN); UV light trap ( $1 \sigma^{\top}$ MNRJ, 2 \% UNAB); manual capture (1 9 MNRJ, 1 ICN, $10^{7}$ UNAB); (Maleza, 10.4500000 -74.4167000), VI.1950, Gallego Montaño, F.L. col. (1 \& MEFLG-13998). Bolívar: San Jacinto (Reserva La Flecha, 324 m, 09 51'12.4"N, $75^{\circ} 10^{\prime} 41.4^{\prime \prime} \mathrm{W}$, tropical dry forest), 16.IV.2018, García, K.
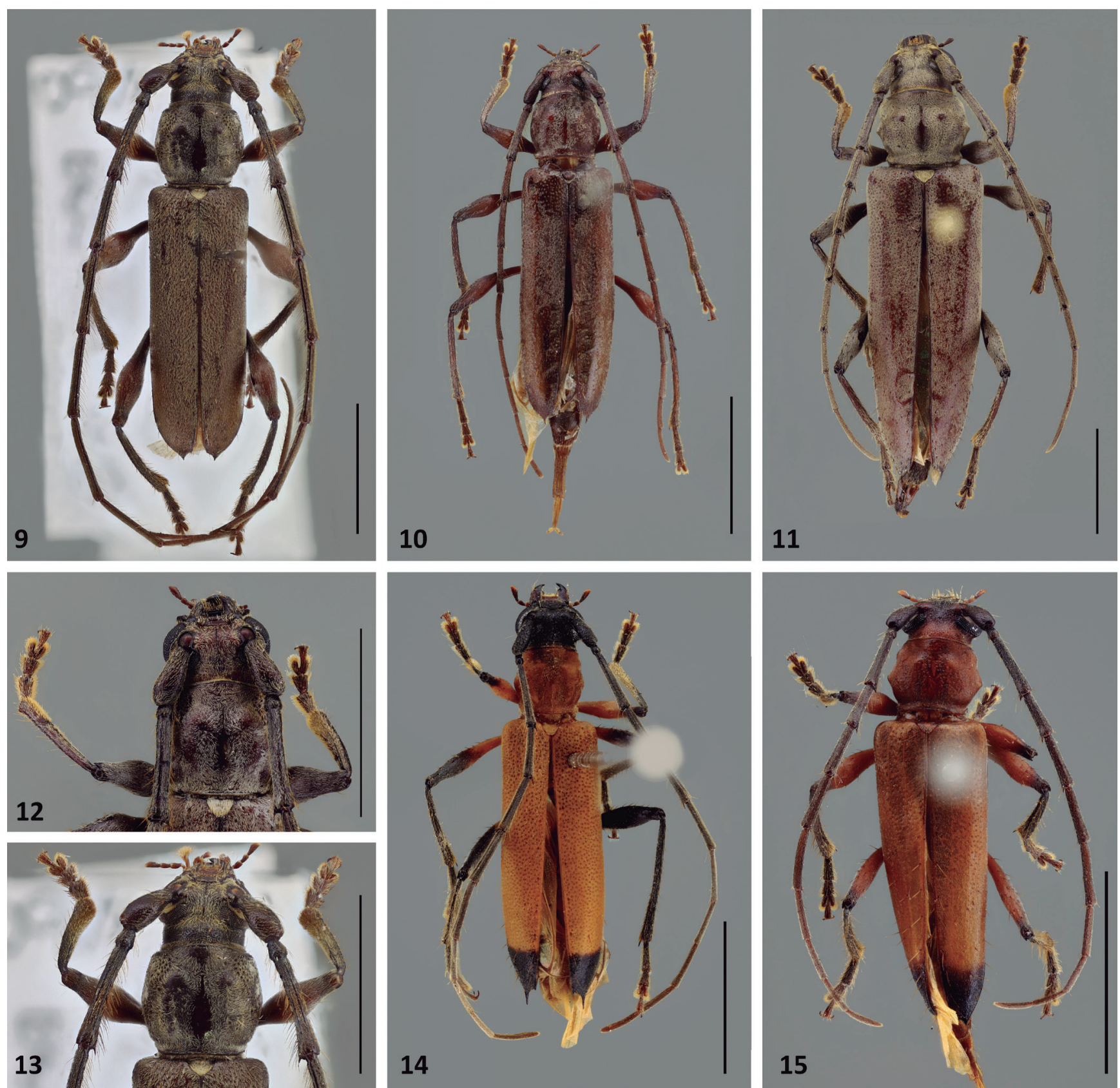

Figures 9-15. (9, 13) Sphaerion sladeni Gahan, 1903: (9) Dorsal habitus; (13) Detail of pronotum and head. (10-12) Sphaerion costae sp. nov., paratype females: (10) Female with lateral margins of prothorax rounded, dorsal habitus; (11) Female with lateral margins of prothorax tuberculate, dorsal habitus; (12) Detail of pronotum and head. (14-15) Mephritus apicatus (Linsley, 1935), dorsal habitus: (14) Male; (15) Female. Scale bars = 5 mm. 
col., manual capture (2 o7 MPUJ_ENT 0069871, MPUJ_ ENT 0070403), white light trap (2 9 , MPUJ_ENT 0070400, MPUJ_ENT 0070402), UV light trap (3 o' MZSP, 8 \%, MPUJ_ ENT 0069872, MPUJ_ENT 0069873, MPUJ_ENT 0069874, MPUJ_ENT 0069875, MPUJ_ENT 0069876, MPUJ_ENT 0069877, MPUJ_ENT 0070399, MPUJ_ENT0070401, 1 우 CEUA); 12-13.V.2018, García, K. col., UV light trap (2 우 CEUA, 1 \% MNRJ, 1 ơ, 1 \& MEFLG); VII.2018, Martinez, N. col., light trap (1 9 UNAB). Magdalena: Santa Marta (Vda. Palangana, Finca Los Nardos, Hostal Olas de Neguanje, $63 \mathrm{~m}, 11^{\circ} 16^{\prime} 41.904^{\prime} \mathrm{N}, 74^{\circ} 07^{\prime} 06.034^{\prime} \mathrm{W}$, Bosque intervenido xerofítico tropical), 05.VI.2019, Neita, J.C. col., light trap (4 o' IAvH-E-214339, IAvH-E-214340, IAvH-E-214341, IAvH-E-214342, 4 \%, IAvH-E-214343, IAvH-E-214344, IAvH-E-214345, IAvH-E-214346); (Reserva biológica Caoba, corregimiento Bonda, Vda. Theran, $347 \mathrm{~m}$, $11^{\circ} 11^{\prime} 33.4^{\prime \prime} \mathrm{N}, 74^{\circ} 03^{\prime} 24.4^{\prime \prime} \mathrm{W}$, Bosque intervenido, tropical alternohígrico), 04.IV.2019, Neita, J.C. col., light trap (2 o' IAvH-E-214347, IAvH-E-214348, 3 \% IAvH-E-214349, IAvH-E-214350, IAvH-E-214351).

Description: Male: Integument reddish-brown. Maxillary and labial palps light brown. Elytra light brown, with pale gold, sericeous pubescence. Antennae reddish-brown; goldish setae on ventral face of antennae. Tarsus light brown.

Head: Frons confluently punctate; deeply and transversally sulcate near clypeus; with sparse, long, decumbent setae. Area between antennal tubercles with deep longitudinal sulcus; confluently, finely punctate; with a few short, decumbent setae. Area between upper eye lobes and towards anterior prothoracic margin with abundant, coarse punctation; and dense, short, decumbent setae obscuring integument. Antennal tubercles sparsely, finely punctate in area close to longitudinal sulcus, denser toward top; with short decumbent setae. Submentum densely rugose; transversally and finely striate on middle area, finely punctate on sides; with fine, short, decumbent goldish setae, abundant in anteromedial area. Genae confluently punctate; with dense decumbent setae, glabrous toward apex. Mandibles rugose on base; sparsely and coarsely punctate toward apex; with deep longitudinal sulcus on dorsal surface. Distance between upper eye lobes 3.7 times width of an upper lobe. Antennae 2.5 times elytral length, reaching elytral apex near middle of antennomere VII. Scape abundantly, finely punctate; with sparse, short, decumbent setae, interspersed with long erect setae, denser at base and laterally. Antennomeres with short, decumbent setae partially obscuring integument; interspersed with long, erect setae mainly ventrally, distinctly more abundant on basal segments. Antennomeres IV-VI dorsally carinate. Antennomeres III-V with short spine at inner apex, smaller on V. Antennomeres VI-XI unarmed. Antennal formula (ratio) based on length of antennomere III: scape $=0.57$; pedicel $=0.14 ; \mathrm{IV}=0.97 ; \mathrm{V}=0.99$; $\mathrm{VI}=0.97 ; \mathrm{VII}=1.04 ; \mathrm{VIII}=0.88 ; \mathrm{IX}=0.87 ; \mathrm{X}=0.76 ; \mathrm{XI}=1.99$.

Thorax: Prothorax equally longer than wide; rounded on lateral margins and unarmed. Pronotal disk with five gib- bosities distinctly elevated; one longitudinal, near middle; two anterior ones, bigger and rounded in shape; two posterior ones elongated. Gibbosities rounded, shiny and microsculptured. Anteromedial margin of pronotum with thick, triangular-shaped area. Surface of pronotum sparsely and finely punctate, coarser and denser laterally; with dense pale yellow pubescence obscuring integument, except for gibbosities. Lateral margins of prothorax moderately, coarsely and deeply punctate; with dense pubescence obscuring integument, interspersed with sparse, long, erect setae. Prosternum with abundant sexual punctation; densely pubescent with a few, sparse, short decumbent setae; anterior region of prosternum transversally, finely striate. Prosternal process densely pubescent; slightly narrowed at middle and slightly expanded toward the apex; width at narrowest point about 0.2 times of procoxal cavity width. Mesoventrite microsculptured; with dense, short decumbent setae on anterior and lateral areas. Mesoventral process pubescent, with sides divergent toward apex; width at narrowest point about 0.7 times of mesocoxal cavity width. Mesanepisternum, mesepimeron and metanepisternum with minute abundant setae almost obscuring integument. Metaventrite microsculptured; with few, sparse, fine punctation; and minute, abundant, decumbent setae except for longitudinal central area. Scutellum densely pubescent; posterior margin rounded.

Elytra: Finely and abundantly punctate, denser on anterior third, sparser toward the apex; with dense pubescence partially obscuring integument; and long, erect setae aligned in three rows; one next to sutural margin, arising from coarse punctation, abundant in the basal region; one in medium area of apical third; and one next to outer margin on apical third. Apex of elytra emarginated with small spine at outer angle, 0.6 times length of pedicel.

Legs: Femora distinctly clavate, mainly meso- and metafemora; microsculptured; with short, decumbent setae obscuring integument, denser dorsally toward apex, interspersed with long, erect setae. Tibiae with longitudinal carinae laterally; with short, decumbent setae, interspersed with long, erect setae at inner face, denser toward apex. Metatarsomere I longer than II-III together.

Abdomen: Ventrites densely pubescent obscuring integument; each with sparse, long, erect setae on posterior margin. Apex of ventrite $V$ truncate.

Variability: Some specimens have lighter integument, reddish and yellowish; denser decumbent setae on head and frons; longer spines at apex of antennomere III; denser pubescence on ventral face of the body, lateral margin of submentum and scape; pronotal disk entirely pubescent (including the gibbosities).

Sexual dimorphism: Females have shorter antennae, reaching elytral apex at apex of antennomere $X$; prothorax with lateral tubercles, acute at apex; prosternum with a few, coarse punctation in the middle, densely pubes- 
cent; ventrite $\mathrm{V}$ longer, trapezoidal, posterior margin truncate. Some females are lighter than the others, with denser pubescence.

Measurements (in $\mathbf{m m}$ ): Holotype, male, total length: 15.5, prothorax length: 3.0, largest prothoracic width 3.3, elytral length: 10.6, humeral width: 3.7. Paratypes, $\sigma^{x} / 9, n=9 / 26$. Total length: $15.3 \pm 5.8 / 16.9 \pm 5.9$, prothorax length: $3.0 \pm 1.4 / 2.8 \pm 0.9$, largest prothoracic width: $3.3 \pm 1.5 / 3.5 \pm 1.2$, elytral length: $10.6 \pm 4.9 / 11.8 \pm 4.1$, humeral width: $3.8 \pm 1.5 / 4.1 \pm 1.4$.

Etymology: The species epithet is in honor of Cleide Costa (MZSP) in recognition of her work and contributions to the knowledge of Coleoptera, especially for immature stages in the Neotropical Region.

Remarks: Sphaerion costae sp. nov., is similar to Sphaerion sladeni Gahan, 1903 (Figs. 9, 13) by the reddish-brown integument, and general pubescence. Sphaerion costae sp. nov., differs by having basal antennomeres barely carinate or lacking carinae; prothoracic pubescence on lateral and ventral sides, lateral pubescence denser, especially on males where it forms a patch; longer elytral spines; and distribution in the Caribbean region of Colombia. Sphaerion sladeni have small spines on elytral apex; prothorax without dense pubescence; antennomeres distinctly carinate; with distribution in the Amazon. A single female specimen from the type series of $S$. costae sp. nov., has the prothorax rounded at sides (Fig. 10), a characteristic that is not present in any species of Sphaerion, or any other similar genera like Mephritus, however, we consider it an aberrant specimen of S. costae sp. nov.

Herein, Sphaerion costae sp. nov., is included in the couplet 4 of Martins (2005) key (translated and modified), along with S. iuasanga and S. lingafelteri according to Galileo et al. (2015) and Galileo \& Santos-Silva (2016):

1. Elytra metallic blue or, rarely, metallic green. Brazil (Goiás, Distrito Federal, Rio Grande do Norte, Paraíba, Bahia, Minas Gerais, Espírito Santo, Rio de Janeiro, São Paulo), Bolivia (Santa Cruz), Paraguay... S. cyanipenne Audinet-Serville, 1834 Elytra without metallic coloration ...... ....2

2(1). Integument dark-brown or reddish-brown..................................... 3 Integument reddish or yellow, sometimes, elytra with dark areas along the suture and on dorsal face of apical half........................ 6

3(2). Reddish-orange head, scape and legs, contrasting with the rest of integument; pronotum wider at posterior third with center glabrous and shiny. Bolivia (Santa Cruz)

S. iuasanga Galileo, Martins \& Santos-Silva, 2015

- Scape and legs similar in color to the rest of the integument; center of pronotum with a short, narrow shining area ..

4(3). Basal antennomeres barely or not carinate; dense prothoracic pubescence lateral and ventrally; long elytral spines. Colombia (Atlántico, Bolívar)..... S. costae sp. nov.

Basal antennomeres distinctly carinate; prothoracic pubescence sparse; short elytral spines.

5(4). Males with antennomeres III-IV each with short spine. Both sexes with elytral apex truncate in short extension; abundant body pubescence; scape slender and narrow toward the apex. Brazil (Rondônia, Mato Grosso, Goiás, Maranhão, Mato Grosso do Sul, Bahia, Minas Gerais), Bolivia (Santa Cruz, Tarija) S. sladeni Gahan, 1903

- Males with antennomeres III-IV unarmed. Both sexes with elytral apex rounded; sparse body pubescence; scape thick toward the apex. Bolivia (Tarija), Paraguay, Argentina (Salta, Tucumán, (haco), Uruguay .............................. S. rusticum Burmeister, 1865

6(2). Dense elytral pubescence, interspersed with contrasting punctures, mainly on apical half; tarsomeres of males thickened. Brazil (Mato Grosso do Sul), Bolivia (Santa Cruz, Tarija), Argentina (Córdoba, Corrientes), Paraguay, Uruguay............. S. lentiginosum Berg, 1899

- Elytral pubescence sparse or absent, without contrasting punctures; tarsomeres of males not thickened..

7(6). Larger dimensions (length, 31-52 mm); antennae, in both sexes, with relatively long spine at antennomeres III-VI. United States (Texas), Mexico (Chiapas, Yucatan), Nicaragua, Brazil (Pará, Piauí, Bahia, Minas Gerais, Espírito Santo, Rio de Janeiro, São Paulo, Santa (atarina), Argentina and Uruguay....

S. exutum (Newman, 1841)

- Smaller dimensions (length, 21-40 mm); antennae unarmed or with minute spines (males) or with very short spines at antennomeres III-VI (females)..

8(7). Antennae (male) longer, exceed elytral apex at antennomere Vl; femora distinctly clavate. Brazil (Mato Grosso, Goiás, Mato Grosso do Sul, Paraíba, Pernambuco, Bahia, Minas Gerais, Espírito Santo, Rio de Janeiro, São Paulo, Paraná, Santa Catarina, Rio Grande do Sul), Bolivia (Beni, Santa Cruz, Tarija), Paraguay, Argentina (Jujuy, Salta), Uruguay. S. inerme White, 1853

- Antennae (male) shorter, exceeding elytral apices at antennomere VIII; femora less distinctly clavate (Fig. 14). Bolivia (Santa Cruz)... S. lingafelteri Galileo \& Santos-Silva, 2016

\section{New geographical records in Elaphidiini}

The following geographical records were based on the catalogs of Bezark (2019), Monné (2019) and Tavakilian \& Chevillotte (2019).

\section{Amethysphaerion falsus Martins, 1995}

Geographical distribution: Venezuela; Colombia (Atlántico), new country record.

Specimens examined: Colombia, Atlántico: Usiacurí; (Reserva Campesina La Montaña, 1046.0'02.6"N, $75^{\circ} 00.2^{\prime} 34.0^{\prime \prime} \mathrm{W}$, tropical dry forest), 12.V.2018, K. García col., white light trap (2\% UARC).

\section{Anelaphus colombianus Martins \& Galileo, 2003}

Geographical distribution: Brazil (Maranhão); Colombia (Bolívar, Magdalena, Norte de Santander, Santander), new department record (Bolívar).

Specimens examined: Colombia, Bolívar: San Jacinto (Reserva La Flecha, 324 m, 0951'12.4"N, 75¹0'41.4"W, 
tropical dry forest), 18.Il.2018, García, K. col., UV light trap (10 UARC); 16.III.2018, García, K. col., UV light trap (19 UARC).

\section{Anelaphus subseriatus (Bates, 1885)}

Geographical distribution: Panama; Costa Rica; Colombia (Atlántico, Bolívar, Magdalena) new department record (Atlántico and Bolívar).

Specimens examined: Colombia, Atlántico: Usiacurí; (Reserva Campesina La Montaña, $10^{\circ} 46.0^{\prime} 02.6^{\prime \prime} \mathrm{N}$ $75^{\circ} 00.2^{\prime} 34.0^{\prime \prime} \mathrm{W}$, tropical dry forest), 15.Il.2018, García, K. col., white light trap (19 UARC); Bolívar: San Jacinto (Reserva La Flecha, $324 \mathrm{~m}, 09^{\circ} 51^{\prime} 12.4^{\prime \prime} \mathrm{N}, 75^{\circ} 10^{\prime} 41.4^{\prime \prime} \mathrm{W}$, tropical dry forest), 17.Il.2018, García, K. col., manual capture (20' UARC).

\section{Anopliomorpha hirsuta (Linsley, 1935)}

Geographical distribution: Mexico (Sinaloa, Mexico, Morelos, Distrito Federal, Guerrero); Honduras; Costa Rica; Nicaragua; Colombia (Bolívar) new country record.

Specimen examined: Colombia, Bolívar: San Jacinto (Reserva La Flecha, 324 m, 0951'12.4"N, 75¹0'41.4"W, tropical dry forest), 14-16.IV.2018, García, K. col., manual capture (10 UARC), white light trap (10' UARC), UV light trap (19 UARC).

\section{Enaphalodes boyacanus Martins, 2005}

Geographical distribution: Costa Rica; Panama; Colombia (Bolívar, Boyacá), new department record (Bolívar).

Specimens examined: Colombia, Bolívar: San Jacinto (Reserva La Flecha, 324 m, 0951'12.4"N, 75¹0'41.4"W tropical dry forest), 15.III.2018, García, K. col., fruit-bated trap (10' UARC).

\section{Mephritus apicatus (Linsley, 1935)}

(Figs. 14-15)

Geographical distribution: Mexico (Chiapas, Oaxaca); Nicaragua; Costa Rica; Panama; Brazil (Rondônia); Colombia (Atlántico, Bolívar), new country record.

Material examined: Colombia, Atlántico: Usiacurí (Reserva Campesina La Montaña, 260 m, 1046.0'02.6"N $75^{\circ} 00.2^{\prime} 34.0^{\prime \prime}$, tropical dry forest), 14.V.2018, García, K. col., UV light trap (19 UARC); Bolívar: San Jacinto (Reserva La Flecha, $324 \mathrm{~m}, 09^{\circ} 51^{\prime} 12.4^{\prime \prime} \mathrm{N}, 75^{\circ} 10^{\prime} 41.4^{\prime \prime} \mathrm{W}$, tropical dry forest), 15-16.IV.2018, García, K. col., UV light trap (3우 UARC), white light trap (10", 1 MZSP).
Remarks: This species was described by Linsley (1935) provisionally in the genus Nephalius Blanchard, 1843, and later transferred to Mephritus by Napp \& Martins, 1982. Originally, Linsley (1935) described the species habitus as yellowish-testaceous, with the head (in front of the eyes), antennae, legs, and apices of elytra black or rufo-piceous; he also mentioned that the elytral apex is spinose but did not specify any variation regarding the length of the spine. Specimens of M. apicatus from Colombia were examined and compared with specimens from the MZSP, and a chromatic variation was noticed. The head was completely dark in some specimens (not only in front of the eyes) (Fig. 14), while others were reddish, only dark in front of the eyes (Fig. 15); the color of the legs is also variable, with a tendency to be dark toward the femoral apex. Moreover, the length of the elytral spines is also variable among specimens.

\section{Parastizocera procera (Erichson, 1849)}

Geographical distribution: Grenada; Mexico; Nicaragua; Costa Rica; Panama; Colombia (Atlántico, Bolívar), new department record (Atlántico and Bolívar); Guyana, Venezuela, Brazil.

Specimens examined: Colombia, Atlántico: Usiacurí; (Reserva Campesina La Montaña, $10^{\circ} 46.0^{\prime} 02.6^{\prime \prime} \mathrm{N}$, $75^{\circ} 00.2^{\prime 3} 34.0^{\prime \prime} \mathrm{W}$, tropical dry forest), 12-15.V.2018, K. García col., white light trap (19 UARC), UV light trap ( $30^{\circ}, 1$ \% UARC); Bolívar: San Jacinto (Reserva La Flecha, 09²1'12.4" $\mathrm{N}$, 75 $10^{\prime} 41.4^{\prime \prime} \mathrm{W}$, tropical dry forest), 13-16.IV.2018, K. García col., manual capture (19 UARC), white light trap (19 UARC).

\section{Psyrassa unisucre Santos-Silva, Botero \& Taboada- Verona, 2017}

Geographical distribution: Colombia (Atlántico, Bolívar, Sucre), new department record (Atlántico and Bolívar).

Specimens examined: Colombia, Atlántico: Usiacurí; (Reserva Campesina La Montaña, $10^{\circ} 46.0^{\prime} 02.6^{\prime \prime} \mathrm{N}$, $75^{\circ} 00.2^{\prime 3} 34.0^{\prime \prime} \mathrm{W}$, tropical dry forest), 12.V.2018, K. García col., white light trap (2ㅇ UARC), UV light trap (19 UARC); Bolivar: San Jacinto (Reserva La Flecha, 0951'12.4"N $75^{\circ} 10^{\prime} 41.4^{\prime \prime} \mathrm{W}$, tropical dry forest), 15.IV.2018, K. García col., white light trap (10' UARC).

\section{Stizocera geniculata (Pascoe, 1866)}

Geographical distribution: Trinidad; Colombia (Atlántico, Magdalena), new department record (Atlántico); Venezuela; Brazil (Roraima, Rondônia).

Specimens examined: Colombia, Atlántico: Usiacurí; (Reserva Campesina La Montaña, $10^{\circ} 46.0^{\prime} 02.6^{\prime \prime} \mathrm{N}$, $75^{\circ} 00.2^{\prime} 34.0^{\prime \prime} \mathrm{W}$, tropical dry forest), 12.V.2018, K. García col., UV light trap (10', 1 o UARC). 


\section{Stizocera lissonota (Bates, 1870)}

Geographical distribution: Panama; Brazil (Pará, Rondônia, Mato Grosso, Mato Grosso do Sul, Maranhão, Piauí, Goiás); French Guiana; Bolivia (Beni, Santa Cruz); Colombia (Bolívar), new country record.

Specimens examined: Colombia, Bolívar: San Jacinto (Reserva La Flecha, 09 $51^{\prime} 12.4^{\prime \prime} \mathrm{N}, 75^{\circ} 10^{\prime} 41.4^{\prime \prime} \mathrm{W}$, tropical dry forest), 25.IV.2018, K. García col., white light trap (19 UARC).

\section{Stizocera poeyi (Chevrolat, 1838)}

Geographical distribution: Cuba; Costa Rica; Panama; Colombia (Bolívar, Tolima), new department record (Bolívar); Venezuela; French Guiana; Brazil (Acre, Amazonas, Rondônia); Bolivia (Santa Cruz).

Specimens examined: Colombia, Bolívar: San Jacinto (Reserva La Flecha, 09 $51^{\prime} 12.4^{\prime \prime} \mathrm{N}, 75^{\circ} 10^{\prime} 41.4^{\prime \prime} \mathrm{W}$, tropical dry forest), 23-16.IV.2017, K. García col., white light trap (19 UARC), manual capture (19 UARC).

\section{Stizocera rugicollis (Guérin-Méneville, 1844)}

Geographical distribution: Nicaragua; Costa Rica; Panama; Colombia (Atlántico), new department record (Atlántico).

Specimens examined: Colombia, Atlántico: Usiacurí; (Reserva Campesina La Montaña, 1046.0'02.6"N, $75^{\circ} 00.2^{\prime} 34.0^{\prime \prime} \mathrm{W}$, tropical dry forest), 14.V.2018, K. García col., manual capture (10', 1\% UARC), UV light trap (1\% UARC).

\section{ACKNOWLEDGMENTS}

The first author is thankful to Antonio Santos-Silva (MZSP) for his kindness, support and training in the identification of specimens; to Juan Pablo Botero (MZSP) for his help and encouragement in the development of this work; to the Universidad del Atlántico (Colombia) for providing the funds to do the sampling and the equipment to analyze the specimens; to the members of "NEOPTERA" team in the Universidad del Atlántico (Colombia), specially to Neis Martínez, Jeniffer Meriño and José Sarmiento who helped in the sampling; to the curators of collections for loans of specimens. The second author is grateful for the grant 2017/15283-9, São Paulo Research Foundation (FAPESP).

\section{CONFLICT OF INTEREST}

Authors declare there is not conflict of interest.

\section{REFERENCES}

Bezark, L.G. 2019. A photographic Catalog of the Cerambycidae of the New World. Available at: http://bezbycids.com/byciddb/wdefault.asp?w=n. Access in: 09/2019.

Botero, J.P. 2018. La familia Cerambycidae (Coleoptera: Chrysomeloidea) en Colombia. In: Deloya, C. \& Gasca, H. (Eds.). Escarabajos del neotropico (Insecta: Coleoptera). Ciudad de México, Sy G Editores. p. 153-169.

Galileo, M.H.M. \& Martins, U.R. 2011. Notas e descrições em Oemini, Dodecosini e Elaphidionini (Coleoptera: Cerambycidae: Cerambycinae). Acta Amazonica, 41(4): 575-582.

Galileo, M.H.M. \& Santos-Silva, A. 2016. Five new species and a new country record in American Cerambycidae (Coleoptera). Zootaxa, 4196(1): 129-143.

Galileo, M.H.M.; Martins, U.R. \& Santos-Silva, A. 2014. New species of Elaphidiini (Coleoptera, Cerambycidae) from Bolivia. Zootaxa, 3884(3): 275-281.

Galileo, M.H.M.; Martins, U.R. \& Santos-Silva, A. 2015. Four new species of Cerambycidae (Coleoptera) from Bolivia and Brazil. Zootaxa, 3985(3): 440-445.

Gounelle, E. 1907. Note sur les genres Sphaerion Serv., Nephalius Newm., Mephritus Pasc., Periboeum Thoms. Et Stizocera Servo (C01.). Bulletin de la Societé Entomologique de France, (1907): 238-244.

Lawrence, J.F; Beutel, R.G.; Leschen, R.A.B. \& Slipinski, A. 2010. Glossary of morphological terms. In: Leschen, R.A.B.; Beutel, R.G. \& Lawrence, J.F. (Eds.). Coleoptera, Beetles. Vol. 2: Morphology and systematics (Elateroidea, Bostrichiformia, Cucujiformia partim). Berlin, Walter de Gruyter. p. 9-20. (Handbook of Zoology, Arthropoda: Insecta)

Lingafelter, S.W. 1998. The genera of Elaphidiini Thomson 1864 (Coleoptera: (erambycidae). Memoirs of the Entomological Society of Washington, 20: 1-118.

Linsley, G. 1935. Notes and descriptions of new or little known neotropical Sphaerionini (Coleoptera, Cerambycidae). Revista de Entomologia, 5(2): 139-149.

Martins, U.R. 2005. Tribo Elaphidionini. In: Martins, U.R. (Org.). Cerambycidae Sul-Americanos (Coleoptera). Taxonomia. Curitiba, Sociedade Brasileira de Entomologia. v. 7, 393p.

Monné, M.A. 2019. Catalogue of the Cerambycidae (Coleoptera) of the Neotropical region. Part I. Subfamily Cerambycinae. Available at: http:// cerambyxcat.com. Access in: 09/2019.

Napp, D.S. \& Martins, U.R. 1982. Mephritus Pascoe, 1866 (Coleoptera, (erambycidae): revalidação do gênero, chave para espécies, notas sinonímicas e descrições. Revista Brasileira Entomologia, 26(1): 71-86.

Tavakilian, G. \& Chevillotte, H. 2019. Titan: base de données internationales sur les Cerambycidae ou Longicornes. Version 3.0. Available at: http://titan. gbif.fr. Access in: 09/2019. 